Nordisk Tidsskrift for Kriminalvidenskab 2004

\title{
BEHANDLINGSTANKENS ÅTERKOMST
}

\section{- FRÅN PSYKOANALYS TILL KOGNITIV BETEENDETERAPI ${ }^{*}$}

Av FIL. DR. ROBERT ANDERSSON

Rehabilitation is making a comeback as a crime prevention strategy. The new epistemology of rehabilitation is based upon the theories and practices of the cognitive behavioural therapy ideal. In this article I attempt to scrutinize this new epistemology employing Michel Foucaults governmentality perspective. I thereby focus on rehabilitation as an element in governance. I start by giving a brief account of the history of the epistemologies of the individualisation sciences. Through their studies of the human individual, and the epistemologies thereby produced, these sciences have played a part in the creation of the object of governance, the individual, and of the ways this governance of individuals is practised. In my examination I look to certain features that I argue are fundamental to it. These features, such as an assumption of some level of free will and a rationale of risk, all come together in producing a new political subject. What I find is that the hierarchical surveillance techniques of the old rehabilitation models are replaced by a horizontal form of surveillance aimed at making the subject see the "obvious" fact that a "normal" person is responsible of his or her actions. What is sought after is a form of self-knowledge, available through the confession of one's faults, which is to be realized through the care of oneself and self-management. The goal of this process is the production of a prudent citizen capable of constituting part of the governmental visions of advanced liberalism.**

Den intagne är en resurs i framtidens kriminalvård. På Östra-gården känner den intagne ett människovärde genom att mötas med insikt och REVANSCH. Han känner att hans resurser (människan bakom brottet) finns och kan tillföra verksamheten utveckling, både sig själv som individ och Östragården som helhet - återigen den lärande organisationen.

Måldokument. KVA Östragård.

"Denna artikel är skriven med ekonomiskt stöd från Nordiska Samarbetsrådet för Kriminologi.

- Title in English: The Re-Emergence of the Treatment Idea: From Psychoanalysis to Cognitive Programmes. Original in Swedish. 


\section{Inledning}

Runt 1820-talets början upptäcks återfallsbrottslingen genom statistiska undersökningar av fångpopulationen (Hacking 1991). Allt sedan dess har kriminalvetenskaperna kämpat med att lösa det problem de själva skapat - hur minskar man återfallen? Genom olika epistemologier, tekniker för att registrera, kodifiera och analysera har man försökt lösa detta problem. Vi har gått från Lombrosos kriminalantropologi, som sökte svaret genom att analysera kroppens geografi, via rasbiologi, Chicagoskolan, kontrollteorier till dagens teorier om rutinaktiviteter och kognitiv beteendeterapi (KBT). Genomgående har det handlat om epistemologier som kategoriserat, kodifierat och ordnat beteenden så att det går att mäta dem. Det handlar alltså om en kunskap som genom sin epistemologi och metodologi har skapat ett subjekt - brottslingen.

Michel Foucault (1987) påvisar hur kriminalvården sedan dess tillblivelse alltid reformerats utifrån sina egna grundprinciper. Detta trots att fängelset var ett misslyckande som brottspreventiv taktik redan från cellstraffets införande. De olika försöken till reformering av fängelsestraffets utformning $\mathrm{i}$ hopp om att nå bättre resultat kan enligt Foucault (1987:312-314) sammanfattas i sju principer: (i) fängelsestraffets huvudsakliga uppgift är att förändra brottslingens beteende och den dömdes förbättring är straffets huvudsakliga syfte; (ii) fångarna bör isoleras eller åtminstone fördelas efter brottets svårighetsgrad, men framför allt efter sin ålder och läggning, efter den korrektionsteknik man avser att begagna och de olika faserna i den förvandling de genomgår; (iii) strafftidens förlopp och längd bör kunna anpassas efter fångarnas individualitet, efter de resultat man uppnår, framsteg och återfall; (iv) arbete bör utgöra ett av de väsentligaste inslagen i fångarnas förvandling och successiva återinpassning i samhället; (v) fångens uppfostran är för myndigheterna på en gång en oundgänglig försiktighetsåtgärd i samhällets intresse och en förpliktelse gentemot den fångne; (vi) fängelsets förvaltning skall åtminstone till en del kontrolleras och ombesörjas av en specialiserad personal som äger de moraliska och tekniska förutsättningarna för att vaka över individernas rätta utveckling; (vii) på fängelsevistelsen bör följa en kontroll- och hjälpverksamhet ända tills den $\mathrm{f} d$ fången är definitivt återanpassad. ${ }^{1}$ Även om inte alla dessa reformeringsprinciper är synliga i denna artikel finns det $\mathrm{i}$ dagens kriminalvård inte heller något nytt som inte ryms inom dessa principer som alltså formulerades redan på 1800-talet.

Min generella utgångspunkt $i$ artikeln är att maktutövning och disciplinering så som den kommer till uttryck i kriminalpolitiken, och i det här fallet kriminalvården, endast utgör en reproduktion av de maktens mekanismer i termer av disciplinering och kontroll som finns i samhället i stort. "Fängelset, vad är det annat än en lite striktare kasern, en litet hårdare skola, en litet dystrare verkstad?" Som jag ser det är det omöjligt att separera de mål och önskningar som används för att 
styra samhället i stort från de mål och önskningar som styr kriminalpolitiken. De mentaliteter, attityder och föreställningar som genomsyrar kriminalpolitiken och kriminalvården återspeglar dem som råder i samhället i stort. Vi skall inte räkna med att finna praktiker inom kriminalvården som inte finns någon annanstans, inte heller tro att det är ett annat subjekt som man försöker skapa inom kriminalvården, det är samma.

Denna artikel handlar om den nya epistemologi som har ersatt psykoanalysens och psykiatrins behandlande, botande och friskställande epistemologi. Tanken är titta närmare på de kunskapsmodeller som informerar den nya behandlingstanken. ${ }^{2}$ Det rör sig om en ny problemställning som tar sin utgångspunkt $i$ en ny samhällspedagogik - det livslånga lärandet. ${ }^{3}$ Den problemställning som finns i denna pedagogik förskjuter fokus med eventuella behandlingsinsatser från ett totalt lösande av ett problem till ett handskande med problem. Det handlar om att lära sig känna igen och handskas med problem för att kunna undvika dessa, vilket görs genom olika tekniker som alla har sin grund i en individuell bekännelseteknik som har sin grund i den katolska bikten (Petersson 2002) och ett risktänkande som ordnar verklighetens beståndsdelar i risker.

\section{Bakgrund}

Min teoretiska modell bygger på de tankar om styrandet och maktutövningens utformning som Michel Foucault (1991a; b \& c) utvecklade runt begreppet governmentalité, hädanefter benämnt styrningsrationalitet. Detta perspektiv går ut på att undersöka styrandet och ordnandet av mänskligt liv och samvaro - hur vi styr våra liv och hur vi blir styrda i våra liv (Gordon 1991). Perspektivet handlar om att synliggöra faktorer som ingår i styrandet som vi vanligen tar för givna och låter bli att problematisera (Dean 1999). Utgångspunkten är att politisk rationalitet handlar om att etablera "problem" och dessa problem, som politiken erbjuder sig själv som lösningen på, lokaliseras i samhället eller hos befolkningen (Dean 1999, Rose 1999). Perspektivet innefattar även att analysera de processer som inramar befolkningen i en trygghetsapparat, bestående av militär, polis, diplomatkår och säkerhetstjänster, rättsväsende, straffsystem, men även vård, omsorg och skola (Dean 1999, Gordon 1991). Kenneth Hultqvist och Kenneth Petersson (1995:26) säger att perspektivet:

(B)idrar med ett generellt sökljus, utan att specificera detaljerna i synfältet - vilket är en uppgift för den konkreta nutidshistoriska undersökningen. (...) Governmentality syftar med andra ord på det förhållandet att maktutövning alltid och i alla sammanhang korresponderar mot en inställning eller ett förhållningssätt till det som ska styras eller påverkas, ja vi skulle rent av vilja benämna denna inställning en förhandsinställning (kursiv i original). 
Språket är ur ett styrningsrationalitetsperspektiv därför inte en fråga om betydelser utan handlar om sätt att göra världen begriplig och användbar och "där domäner som 'marknaden' och 'familjen' konstitueras för att sedan göras mottagliga för interventioner såväl från administratörer, politiker, myndigheter och experter som dem som befolkar dessa domäner, dvs. fabrikschefer, föräldrar och andra" (Rose 1995a:47).

\section{Individualiseringsvetenskapernas epistemologier historiskt sett}

Individualiseringsvetenskaperna, d.v.s. de vetenskaper som på olika sett har individen som fokus för sina studier, har en tämligen ung historia, men deras betydelse för den verklighet vi lever i nu är utomordentligt stor. Själva uppdelningen av samhället $\mathrm{i}$ individer istället för exempelvis stånd hänger intimt ihop med naturvetenskapernas upptäckt av atomen och själva begreppet individ är en latinsk synonym till ordet atom (Liedman 1998). Även John Lockes föreställning om individen som en tabula rasa är central i utvecklandet av discipliner vars grund är att människor kan ändras via skolning, fostran eller behandling.

Som Michel Foucault framhållit i flera av sina arbeten sker det under 1700- och 1800-talen något betydelsefullt genom framväxten av det han benämner humaneller individualiseringsvetenskaperna. I samverkan med makten utvecklas en kunskap om människor som tidigare inte funnits, en kunskap som är avgörande för det nya sättet att handskas med det Foucault (1991a) benämner befolkningsproblemet. De maktformeringar som växer fram genom demokratiseringen är starkt bundna till en kunskap om det som skall styras, nämligen befolkningen och medborgarna. Här är kriminalvetenskapernas uppkomst samtida med uppkomsten av fängelset och avgörande i skapade subjektet för fängelsestraffet, brottslingen. ${ }^{4}$

Individualiseringsvetenskapernas epistemologier har legat till grund för hur vi förstått individen och dennes beteende och har därigenom konstituerat och skapat subjektet för maktutövning (Rose 1998). Dessa epistemologier har fungerat som normproducerande, utifrån vilka man har kartlagt och bedömt aspekter av mänskligt beteende som fram till dess betraktats som tillfälliga och oförutsägbara. När bestraffningsformen fängelset kom i bruk, en åtgärd riktad mot brottslingen och inte brottet, behövdes en kunskap om vad brottslingen är för något. I det utrymmet träder psykiatrin in genom att producera just kunskap om brottslingen, vad han är, hur han ser ut, vad som driver honom och så vidare (Foucault 2000). Genom dessa kunskapsformer har beteenden kunnat bedömas i termer av konformitet och avvikelse och de normer som upprättats har gjort det möjligt att kodifiera, rangordna, mäta och jämföra mänskligt beteende (Latour 1986). ${ }^{5}$ Individualiseringsvetenskaperna har skapat scheman som gjort beteenden både synliga och föremål för kunskap - beteenden har blivit identifierbara och registrerbara utifrån det raster av sociala koder som begreppen konformitet och avvikelse börjat sprida över det sociala livet (Rose 1995b). 
Individualiseringsvetenskaperna innefattar vad man skulle kunna benämna visualiseringstekniker - de möjliggör ett seende av det som är deras studieobjekt. ${ }^{6}$ Med andra ord kan man säga att den kunskap som dessa vetenskaper producerar egentligen är ett skapande av vad som kommit att tolkas som naturliga kategorier som brottslingar, avvikare, ungdomar, svagsinta och problemfamiljer. Den kunskap som dessa vetenskaper producerar skapar alltså de subjekt som det blir statens och dess myndigheters uppgift att styra, handha och kontrollera.

Den första formen av visualiseringsteknik för registrering av människors skillnader som producerades framställde kroppens yta som det fält där avvikelser kunde utläsas och observeras. Här har vi bland annat Lombrosos studier av homo criminalis. Genom att mäta kroppens yttre proportioner och karaktäristika trodde man sig kunna studera det patologiska subjektet och systematiskt kartlägga osynliga mentala karaktäristika (Rose 1998). Efter ett tag blev det dock uppenbart att olika förmågor och särdrag som påverkade skolresultat, kriminalitet och andra avvikelser inte kunde utläsas på kroppens yta.

En ny epistemologi tog sig då an uppgiften att lokalisera och visualisera avvikelsen och fann dess ursprung i den sinnesslöe. Den sinnesslöe utgjorde ett hot mot samhällets fortbestånd och det behövdes verktyg för att kunna identifiera denne. ${ }^{7}$ Ett verktyg som utvecklades för att hitta den sinnesslöe blev mätandet av intelligens och intelligenstestandet slog igenom med införandet av allmän skolgång ${ }^{8}$ i England och Frankrike (Rose 1995b). ${ }^{9}$ Normalkurvan blev ett annat viktigt verktyg. Med den kunde befolkningens intellektuella förmågor konstrueras i en enkel modell där dugligheten hos varje subjekt kunde fixeras och reduceras till en position på den aktuella kurvan (Rose 1995b).

Framme vid mellankrigstiden hade individualiseringsvetenskaperna befäst sin position i samhällets maskineri. Vetenskapsmannen var den givna experten - en social ingenjör som med sina kalkyler och ekvationer över vansinnet och avvikelsen kunde räkna ut det riktiga tillvägagångssättet. Denna position, med sin positivistiska vetenskapsoptimistiska rationalitet, kom att nå sin höjdpunkt på 1950 -talet, och sin ände vid 1960 -talets slut. ${ }^{10}$

Från Freuds psykoanalys, över Bleulers psykiatri till Skinners behaviorism finns det gemensamma grundförutsättningar: För det första relationen Läkare patient; för det andra vetenskapernas möjlighetspotential, vetenskapsoptimismen; för det tredje samhällets förgivettagande, dvs. relationen samhälle och stat som en enda storhet som samverkar mot gemensamma mål. I allt detta ligger skapandet av ett politiskt och medborgerligt subjekt som utgjorde grunden till, samt var det rådande under den så kallade välfärdsstatens styrningsrationalitet.

Under det sena 1960-talet växte en stark kritik fram mot den vetenskapsoptimism som genomsyrade välfärdsstatens välfärdsarbete och de orättvisor som 


\section{NORDISK TIDSSKRIFT FOR \\ KRIMINALVIDENSKAB}

\section{REDAKTION}

RAGNHEIDUR BRAGDÓtTIR

Professor, cand. jur.

Reykjavik

HaNS von Hofer

Professor, jur. dr. Stockholm

Kimmo Nuotio

Professor, jur. dr.

Helsing fors

\section{KJERSTI ERICSSON}

Professor, cand. psychol.

Oslo

Britta KyvsgaARD

Forskningschef, dr. jur.

Hovedredaktør

København

HILDIGUNNUR ÓlaFsDotTIR

Forsker, dr. philos.

Reykjavik

\section{Per Ole Träskman}

Professor, jur. dr.

Lund 
Nordisk Tidsskrift for Kriminalvidenskab er trykt af

DE GRAFISKE FAG - STATSFANGSLET I NYBORG

Vindingevej 36, DK-5800 Nyborg

ISSN 0029-1528 


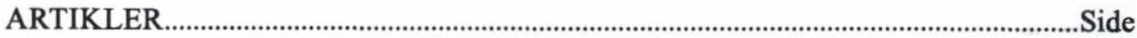

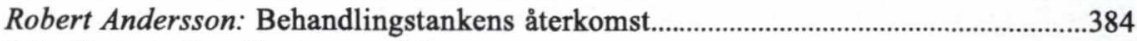

Nils Christie: Straffen som problem.......................................................................................302

Jørn R.T. Jacobsen: Allmennprevensjon og straff.................................................................311

Lars E. Korsell: Straff och självreglering mot brott i näringslivet.................................349

Peter Kramp og Gorm Gabrielsen: Benådning på grund af psykisk lidelse.....................39

Kimmo Nuotio: En kritik av kritiken..................................................................................1

Leif Petter Olaussen: Hvorfor er kriminalitet en sosial realitet?....................................24

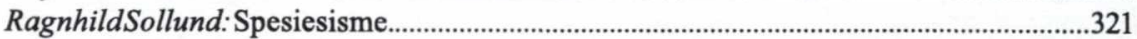

Paulina Tallroth: Språket och internationell rättspraxis...............................................368

\section{DEBAT}

Nils Christie: Hvorfor det er ufruktbart å ta utgangspunkt i at kriminalitet

er en sosial realitet 404

Leif Petter Olaussen: Kriminalitet er en sosial realitet. 408

\section{INDLÆG VED XIII NORDISKA KRIMINALISTMÖTET}

Jan Andersson: Brottsutvecklingen i Sverige 1980-2003.

Kauko Aromaa: Brottsutvecklingen i Findland 1980-2002 ..............................................80

Flemming Balvig: Kriminalitetsudviklingen i Danmark og omegn...............................94

Agneta Bäcklund: Utvecklingen av straffrättsliga påföljderna i Sverige.......................255

Ragnheidur Bragadóttir: Udviklingen af de strafferetslige sanktioner i Island...........232

Thomas Elholm: Aktuel europæisk strafferetsudvikling................................................194

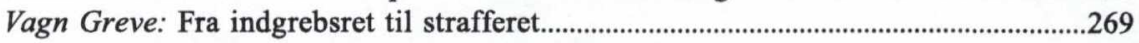

Helgi Gunnlaugsson: Kriminalitetsudviklingen i Island...............................................110

Tarja Halonen: Tal av republikens president.......................................................................269

Ragnar Hauge: Kriminalitetsudviklingen i Norge siden 1980.....................................124

Erling Johannes Husabø: Strafferetten og kampen mot terrorismen..............................180

Tapio Lappi-Seppälä: Utvecklingen av straffrättsliga påföljder i Finland...................206

Magnus Matningsdal: Utviklingen av strafferettslige reaktioner i Norge....................243

Kirsti Nieminen: Den sanna historien om Tommy...........................................................144

Per Ole Träskman: Föränderligt och oföränderligt...........................................................160

\section{BOGANMELDELSER}

Marianne C. Brantsater af INGRID LANDER: Den flygande maran..........................413

Susanne Clausen af JERZY SARNECKI: Delinquent Networks.................................55

Thomas Elholm af RETSSIKKERHEDSKOMMISSIONENS BETÆNKNING, betænkning nr. 1428 ..

Peter Garde af OLAF KIESCHKE: Die Praxis des Europäischen Gerichtshofs für

Menschenrechte und ihre Auswirkungen auf das deutsche Strafverfahrensrecht. 
Linda Gröning av PETTER ASP: EU \& Straffrätten

Hans Klette av ANDREW ASHWORTH: Human Rights, Serious Crime and

Criminal Procedure. .340

Peter Kramp af GEORG HØYER OG ODD STEFFEN DALGARD:

Lærebok i rettspsykiatri .63

Britta Kyvsgaard af ANDERS NILSSON: Fånge i marginalen........................................58

Sven-Ake Lindgren av ROBERT ANDERSSON: Kriminalpolitikens väsen.................336 Matti Marttunen av JOHN MUNCIE, GORDON HUGHES \& EUGENE MCLAUGHLIN:

Youth Justice; Critical Readings 416

Hanne Olesen af YNGVE HAMMERLIN OG RAGNAR KRISTOFFERSEN:

Vold og trusler mot tilsatte i kriminalomsorgen. 344

Peter Scharff Smith af WENCHE BLOMBERG: Galskapens hus. 346

Bettina Schütz-Gärdén av PILAR GONZÁLES-RIVERO: Strafrechtliche Zurechnung bei Defektzuständen. Zugleich ein Beitrag zur allgemeinen Zurechnungslehre...425 Anette Storgaard af ANTHONY BOTTOMS, LORAINE GELSTORPE,

SUE REX: Community Penalties, Change and Challenges

Katja Franko Aas af ZYGMUNT BAUMAN: Frihed. .423

NY LITTERATUR. $.70,268,426$ 
framför allt dess institutioner producerade. Inom kriminologin är detta fenomen känt som behandlingskritiken. ${ }^{11}$ Denna kritik av kriminalpolitiken är central för de förändringar som inträffat från 1970-talet till i dag och utgör även fundamentet för de idéer som den nya behandlingsepistemologin lanserar. Vetenskapsoptimismen och möjligheten till storskaliga vetenskapliga lösningar på "problem" är nertonad - universallösningarnas tid är förbi. Borta är också den allvetande experten och relationen Läkare/patient - diagnos/botande. I dess ställe har ett möte av "jämlikar" kommit, där den vetenskapliga kunskapen bytts ut mot en kunskap baserad på sunt förnuft. Borta är också samhällets förgivettagande, numera handlar det om community eller lokalsamhället, det handlar om lokala lösningar på lokala problem. Den nya behandlingstankens uppgift är att tillsammans med andra vetenskapliga praktiker skapa ett nytt subjekt för maktutövningen - den moraliske, förståndige och ansvarsfulle medborgaren. ${ }^{12}$

\section{Den nya epistemologin}

Så fort som kritiken mot det som vanligen kallas behandlingstanken ${ }^{13}$ slagit igenom tidigt 1970-tal påbörjades en utveckling av de verktyg som använts av behandlingsteknikerna. Tankarna kring selektiv inkapacitering är ett exempel på hur man snabbt reagerade på kritiken om oförmågan att göra de intagna friska med expertis. Selektiv inkapacitering tar avstånd från alla rehabiliteringsanspråk - det man istället säger sig kunna göra är att ta reda på vilka som kommer att återfalla i brott. Den argumentering som framförs mot behandlingskritiska studier som exempelvis Lipton m.fl. (1975) är att dessa bygger på ett felaktigt antagande när de i sina utvärderingar kräver generellt tillämpbara åtgärder, något behandlingsförespråkare menar att man inte kan förvänta sig finna (Lab 2004). Denna reducering av kraven på generaliserbarhet inom forskningen framkommer också i Ronald Clarkes (1980) teori om situationell brottsprevention.

Även kognitiv beteendeterapi (KBT) förutsätter minskade anspråk gällande vetenskaplig optimism - utgångspunkten är att lära ut olika tekniker för att lära sig handskas med sina "problem". ${ }^{14}$ I en kognitiv terapi är det terapeutens uppgift att leverera tekniker för att individen skall kunna bryta sönder negativa tankescheman. KBT bygger, kanske $\mathrm{i}$ ännu högre grad än klassisk psykoanalys, på metodologiska modeller som är beroende av kontextuella normativa föreställningar som omsätts i begrepp som "bristande självkontroll", "hög impulsivitet" och "oförmåga att se konsekvenserna av ens handlingar". Avvikande beteende är helt enkelt ett uttryck av "bristande personliga färdigheter". En syn på avvikelse som även kontrollteorin är uttryck för.

Istället för universella lösningar bygger dessa idéer på att producera kontextuella lösningar, vetenskapernas anspråk går alltså från det universella svaret till det partikulära. ${ }^{15}$ Här framstår rutinaktivitetsteorin som ett utmärkt exempel. 
"Teorins" svar på varför brott begås är helt kontextuell, samtidigt som den är universellt tillämbar bara man tar hänsyn till den specifika kontexten. David Garland (2001) talar om hur man inom kriminalpolitiken i Storbritannien och USA håller på med en process han benämner redefining success. Som jag ser det är det just vad dessa förändrade förväntningar på vetenskaperna handlar om - de stora vetenskapliga idealen med universallösningar omdefinieras till målsättningar som är tämligen små och specifika, samtidigt som de ska vara lätta att utvärdera. Steven Lab (2004:294) säger om den nya behandlingsforskningens resultatmått att: "(p)erhaps the most common outcome measure in the rehabilitation literature are those that do not look to recidivism and deviant behaviour". Istället utvärderar man saker som förändringar av självkänsla, språkhantering, attityder och anpassningsförmåga.

Jag kommer nu att gå igenom ett antal företeelser som jag menar är grundläggande i den nya epistemologin.

\section{Den fria viljan och risktänkandet}

Tanken på att vi har någon form av fri vilja är en grundförutsättning för att ens kunna formulera de påverkansprogram som bygger på KBT. Den påverkan som skall göras handlar ju om att förändra hur "brottslingen" tänker. På kriminalvårdsverkets hemsida (www.kvv.se) säger man så här:

Förändrat beteende åstadkommes på ett effektivt sätt genom att ändra på vad vi tänker och hur vi tänker. Känslor, tankar och beteende hänger alltid ihop på något sätt. Ändrar vi på en av dessa faktorer, påverkas alla tre. När vi arbetar med kognitiva metoder, fokuserar vi på tankeprocessen som den mest användbara för att åstadkomma förändringar.

Tidigare har de orsaker som framförts som kausala för brott varierat från fysisk predisposition till socialstrukturell determinism - förklaringsformer som lämnat litet eller inget utrymme till en fri vilja. Ser vi till de kriminologiska teorier som utvecklats efter 1960- och 70-talens behandlingskritik, som kontrollteorier och rutinaktivitetsteorin, är även de idéer som förutsätter en fri vilja av den typen KBT utgår från. ${ }^{16}$ Tittar man då på hur KBT-programmen är uppbyggda handlar det vanligen om sju block där det första är att lära sig problemlösning där "(m)an lär sig skilja mellan fakta och åsikter samt att hämta information för bättre ställningstaganden i olika situationer". För det andra tränas man i sociala färdigheter där social kompetens är att "lära sig ett beteende som leder till färre problem". För det tredje lär man ut förhandlingsfärdighet där man "lär sig att kunna acceptera kompromisser, undvika konflikter genom att ge och ta i det dagliga livet samt att finna alternativ genom att analysera olika konsekvenser när de ställs i en valsituation". För det fjärde lär man ut hantering av känslor genom att behandla "hur det känns när vi börjar få problem, vad som gör oss upprörda och hur ilska utlöses". 
Det femte blocket består i att lära ut kreativt tänkande med syftet "använda sin fantasi för att undvika enkla lösningar som ofta leder till problem". Ett sjätte led består i att lära sig värderingar som innebär "att genom aktivt lyssnande, diskussioner och ett öppet synsätt lära sig acceptera andra". Slutligen lär man ut kritiskt tänkande där "(d)eltagarna tränas i att tänka grundligt, logiskt och rationellt". I den avancerade liberalismens styrningsrationalitet är förmågan att göra val på exempelvis den fria marknaden avgörande för subjektets skapande. Nikolas Rose (1999:161) säger om det nya subjekt som eftersöks i den avancerade liberalismen att " $(t) h e$ new citizen is required to engage in a ceaseless work of training and retraining, skilling and reskilling, enhancement of credentials and preparation for a life of incessant job seeking: life is to become a continuous economic capitalization of the self" ${ }^{17}$ Frågan är dock hur vi skall informera vår valsituation? Jo, genom ett risktänkande vari vi kan kalkylera utgången av våra val.

Risktänkandet är det förhållningssätt som ersatt "det moderna" som metaberättelse genom att tillhandahålla "kunskap" om framtida skeenden (se exempelvis Beck 2000) ${ }^{18}$ Förnuftet i det moderna förknippades med vetenskapsoptimism och innebar att det gick att ha kunskap om framtiden. Med risktänkandet har förnuftet omdefinierats till att handla om mer kortsiktig kunskap om hur vi bör handla för att undvika oönskade konsekvenser. Det är förnuftigt att ta hänsyn till de olika risker som är förknippade med ens olika valmöjligheter.

Risk skall förstås som ett kontinuum. Vi lever hela tiden med olika risker och att ta hänsyn till dessa och beräkna vårt handlande utifrån dessa risker är vad den nya synen på förnuftigt handlande går ut på. Risk kan hanteras, minimeras, lokaliseras och undvikas, men aldrig helt utraderas. Robert Castel (1991:288) säger om risktänkandet som politisk strategi att "(o)ne does not start from a conflictual situation observable in experience, rather one deduces from a general definition of the dangers one wishes to prevent. These preventive policies thus promote a new mode of surveillance: that of systematic predetection" (kursiv i original). Häri ligger grunden till utformandet av olika program inom kriminalvården för upptäckandet av just risk - att göra riskbedömningar av "klienterna" är en huvudsyssla inom dagens kriminalvård. ${ }^{19}$ Risktänkandet informerar alla nivåer av systemet, allt från personutredningar och bedömningar av vilka som kommer att återfall, till hur de som genomgått KBT skall analysera sina val av handlingar - det handlar om en beslutsteknik tillämpbar överallt.

\section{Anti-expertis}

Ett fundament i den nya behandlingstanken är dess anti-expertis tillämpning. ${ }^{20}$ Med detta inte sagt att det inte är experter som tagit fram "kunskapen", vad det handlar om är snarare relationen forskning - praktisk tillämpning. Det är den egna erfarenheten och framför allt tillvaratagandet av den egna erfarenheten som ger 
den praktiskt tillämpbara kunskapen. Både hos den intagne, som skall lära sig beakta riskerna i sin egen livsföring utifrån att denne lär sig känna igen och förstå sitt beteende och vårdarens erfarenheter av att ha liknande "problem" som den som skall vårdas. Borta är den ovan den krassa verkligheten stående forskaren, som ger direktiv från sitt verklighetsfrånvända laboratorium. ${ }^{21}$ Den nya behandlingstanken har helt enkelt en "mer verklighetstillvänd" kunskap. Den erfarenhetsbaserade kunskapen har formen av möte - igenkännande - bekännelse. Grunden för den är; Jag har varit där, jag vet hur det är eller hur det ser ut.

Sålunda var det viktigt vilken typ av missbruk som behandlingspersonalen tagit sig ur. Man måste underlätta för patienten att identifiera sig med personalen. För en missbrukare är det en bragd att ta sig ur missbruk, att stått utanför samhället och återtagit sin position inom samhällets ramar. De som arbetade hos oss hade tagit sig ur missbruk de besatt kunskaper om hur man gjorde det och stod modell för inlärning av ett nytt, bättre liv. De gav hopp. ${ }^{22}$

Kunskapen är alltså ett sunt förnuft som uppstår ur bekännelsen - ett bekännande av hur det verkligen är.

Framväxten av en expertstyrd och av professionella skött kriminalvård var inte given på förhand. Religiösa grupper som kväkarna i USA drev fängelser (Wallén 1979), tanken att just polisen skulle sköta lagens upprätthållande är en sen tanke (Garland 1996) och i Sverige växte en kår av frivårdare fram på grund av den villkorliga frigivningens införande 1906 (Häthén 1990, Svensson 2001). Under större delen av 1900-talet har staten allt mer kommit att ta över drivandet av institutioner som verkat för barnavård, sjukvård, missbruksvård och kriminalvård. Allt detta som ett led i ett behandlingstänkande som Claes Levin (1998) benämner den socialpolitiska behandlingstanken. Behandlingstänkandet har alltså gått från att många gånger ha starka inslag av filantropi till ett statligt övertagande genom införandet av professionella yrkesgrupper. Nu är filantropin på väg tillbaka i stor stil som lösning på många problem inom kriminalpolitiken. Här kan nämnas företeelser som Farsor och Morsor på Stan och Lugna Gatan-projektet, två typer av frivilliga insatser för att minska våldet.

En förklaring till detta skeende är ansvarsgörandeprocessen (Andersson 2002, Garland 1996; 2001). Vi som privatpersoner skall ta större ansvar för våra egna och andras liv samtidigt som staten minskar sitt ansvarsområde. Ett område där ansvaret har förskjutits från staten till individen är sjukvården, eller som det numera heter hälsovården. Sarah Nettelton (1997:208) säger om detta att: "(h)ealth is something which lies within the control of the individual. All active citizens have a right and a duty to maintain, contribute to and ensure (or should that be insure?) their health status". Även inom kriminalpolitiken sker detta ansvarsgörande och tar sig uttryck i allt från gated communitys till grannsamverkan mot brott (Andersson 
2002). Experten arbetar idag inte genom att sätta upp regler och kräva dess genomförande, utan genom att tillhandahålla och bistå med råd och information som det är upp till den enskilde att handskas med utifrån ett risktänkande (Rose 1999).

\section{Själen som kroppens fängelse - självförvaltning som styrningspraktik}

Man kan, för att tala med Michel Foucault, säga att själen är kroppens fängelse. Detta kan exemplifieras med en enkel pedagogik som bland annat kommer till uttryck i den i barnuppfostran vanliga devisen - sätt gränser och väx. Det moderna samhället bygger på en disciplineringsprocess som skall omvandla de utifrån komna kraven på beteende till ett krav som kommer inifrån i form av självdisciplin. Som exempel på detta har vi ett begrepp som blivit stort inom kriminologin - socialiseringsprocessen. Uppfostran handlar nästan uteslutande om att lära människan att sätta upp stängsel kring sina spontana viljor för att de skall "passa ihop" med andra. En viktig del i den nya epistemologin är hur dessa gränser är tillgängliga. Tidigare skulle experten via botandet lära ut och tillgängliggöra dessa gränser. Ett botande som hade sin grund i den kunskapsmässiga överlägsenheten hos experten som låg inbyggd i den läkare - patient relation som var tillgängliggörandets grundförutsättning. Den bekännelseprocess som låg till grund för denna epistemologi byggde på en hierarkisk relation och därigenom en hierarkisk övervakning. Det nya tillgängliggörandet av gränser sker via bekännelsen och möte med "jämlikar". I detta ligger en horisontal istället för hierarkisk övervakning. Grundläggande i behandlingstankens nya epistemologi är att behandlingen skall lära de intagna subjekten att skapa sitt eget fängelse genom att lära sig självkontroll. Kenneth Petersson (2002:56) uttrycker det så här:

Det faller liksom på den intagnes lott att lyckas eller misslyckas med detta att förse sig med murar och staket inom sig själv. Den intagne måste inför sig själv rita upp ett fungerande fängelse, vars omarkerade gränser styr honom att mentalt vakta på varje steg. Man måste helt enkelt göra det öppna fängelset till en del av sig själv.

Själva kärnan i KBT är ju att avvikande beteende uppstår på grund av brister och tillkortakommanden i det egna tänkandet och självkontrollen. Det viktigaste verktyget i tillämpande av självkontroll är det som benämns riskanalys och riskhantering. Självkontrollen tycks gå ut på att man hela tiden skall göra riskanalyser av sitt eget beteende som man lär sig känna igen genom bekännelsen. I detta ligger även det livslånga lärandet, man måste hela tiden lära känna sig själv och ens tillkortakommanden om och om igen. Även om denna idé om självreformation inte är ny, utan går igen i allt från bikten till Auburnsystemets tysta fångar, är det mötet med de egna tillkortakommandena, inte de av Gud eller annan auktoritet givna reglerna, som är viktigt. 


\section{En evidensbaserad metod}

Senare tids behandlingsforskning har dock i hög grad inriktats på att identifiera faktorer som påverkar benägenheten att begå brott och åtgärder som har effekt när det gäller att minska riskerna för återfall i brott. Uppföljning och utvärdering har blivit centrala begrepp i verksamheten. Denna utveckling mot en kunskapsbaserad verksamhet är mycket positiv och möjliggör en prioritering av de insatser som ger bäst resultat (Dir 2002:90, s. 3).

En dominerande föreställning i etablerandet av den nya epistemologin är att man nu bedriver bättre forskning om behandlingsinsatser än tidigare. ${ }^{23}$ Man tycks mena att teknikerna mätbarhet och utvärdering är något som inte använts tidigare, i alla fall inte så precist som av dessa forskare. ${ }^{24}$ Dessa tekniker är också de som behandlingskritikerna förde fram i sin kritik av behandlingstanken. Detta leder till att vad som blir viktigt är att formulera det man menar vara konkreta mål som är just utvärderingsbara. ${ }^{25}$ Detta innebär att målet med vetenskap förskjuts till ett oerhört praktiskt plan, återigen träder samhällsingenjörer fram nu med utvärderingstekniker till sitt förfogande. Man minskar helt enkelt målsättningarna med vetenskap - predicera ja, kurera nej! Handskas med ja, lösa nej!

Ser man exempelvis till hur David Perry, chef för What works på Home Office, framställer sin verksamhet framstår utvärdering av drivna kriminalvårdsprojekt som något nytt (KVS 2002). Evidensbaserad verksamhet beskrivs som något oprövat och radikalt. I en antologi med James McGuire (2002) som redaktör återkommer man hela tiden till att den forskning man säger sig producera är så starkt evidensbaserad. När man läser artiklarna får man nästan känslan av religiös övertygelse och pionjäranda - vad dessa forskare gör har aldrig gjorts tidigare, $i$ alla fall inte så effektivt och grundligt. ${ }^{26}$ Även i direktiven till den nya kriminalvårdslagsutredningen kommer denna mentalitet till uttryck när det framhålls att verkställigheten av påföljder: "skall bygga på kunskap om vad som är verkningsfullt för att uppnå olika resultat. För att verksamheten skall utvecklas, resultat kunna mätas och riktiga prioriteringar göras är det nödvändigt att det som görs dokumenteras, följs upp och utvärderas" (dir. 2002:90, s. 5). Ett sätt att försäkra sig om att de rätta prioriteringarna görs är att som Perry säger - ackreditera projekten innan de drivs i större skala.

Det ekonomiska språkbruket, med marknads- och efterfråganstänkande är oerhört starkt i exempelvis de beskrivningar Perry ger. Cost/benefit-analyser, investeringar i kriminalvård, att England skall bli världsledande inom kriminalvård, att det handlar om att designa och implementera kriminalvård. Malcolm Feelys och Jonathan Simons $(1992 ; 1994)$ tankar kring det de benämner the new penology och manageralism känns starkt närvarande i hur problemställningarna och lösningarna framställs. Även direktiven till den nya kriminalvårdslagsutredningen bär till stora delar denna ekonomins språkdräkt (dir. 2002:90). 
Tittar man dock närmare på vad som detta med evidenssäkring kan handla om i praktiken kan fokuseringen på hur mycket återfallen minskar lika väl flyttas över på saker som är lättare att utvärdera som exempelvis personalens förmåga att genomföra olika program. Relevant är att övervakarna övervakas lika mycket genom att man evidenssäkrar uppställda kvalitetskrav ifråga om att kunna förmedla programmen, och utvärderar personalens utförande av programmen. Därför förvånar det inte när Perry säger:

Vi började göra bedömningar av vår egen personal. Vi ville inte att de skulle ha samma kognitiva problem som de kriminella, ifall de skulle leda program. Vi började alltså med att söka brister hos vår personal och fann en hel del hos många av dem (KVS 2002:58).

Dessa bedömningar har nu införts som standard vid nyrekrytering.

Den moderna bestraffningsapparaten har sedan sin födelse inneburit utvecklandet av nya professioner som poliser och vetenskaper som kriminologi. Socionomutbildningen infördes i Sverige på grund av att man ville ha professionella som skötte bland annat eftervården och frivården (Svensson 2001). När Perry då framhåller att den klassiske socialarbetaren inte fungerar i den nya kriminalvården förvånar det inte. Inte heller överraskar det att han har önskemål om en ny högskoleutbildning för den nya kriminalvården - en kriminalvård som enligt Perry skall handla om att arbeta mer med att lära ut och utbilda.

\title{
Bekännelsen och självdiagonsticerandets praktik
}

\begin{abstract}
Det är ett krav för att få stanna kvar i programmet att personen pratar om återfallet $\mathrm{i}$ gruppen och av gruppen och gruppledarna får hjälp att analysera och bearbeta det som skett. Syftet är att alla skall lära sig något av detta, såväl den som återfallit som gruppen. Att tillsammans med gruppen analysera återfallet kan till den det berör ge en djupare kunskap om dennes relation till alkohol och luckra upp en del av förnekandet. ${ }^{27}$
\end{abstract}

Den nya praktiken till skillnad från psykoanalysens praktiker av botande handlar om lärandet och erkännandet via bekännelse. Som grundmodell i de olika påverkansprogram gällande missbruk som finns inom svensk kriminalvård är Anonyma Alkoholisters tankemodeller en huvudsaklig inspiration (Petersson 2002). Vad man säger sig sträva bort från i svensk kriminalvård är vedergällning, passivitet och hjälplöshet, tanken är att man bör komma bort från ovanifrån införda direktiv och dikterade förändringsbehov - skeenden som man menar leder till underkuvelse. ${ }^{28}$ Vad man vill nå är självbestämmande, självreglerade val och man anser sig nå dithän genom att uppmuntra inaktiva att bli aktiva och självmotiverade, det man vill betona är samarbete och interaktiv kommunikation. Det handlar om att via självbekännelsen få det styrda subjektet att producera sanningen om sig själv (Petersson 2002). 
I grund och botten är det denna omfattande bekännelseprocedur inom svensk kriminalpolitik som ligger till grund för den samtidiga iscensättningen av "det goda livet". Men denna procedur är ingen isolerad företeelse utan inom den svenska kriminalvårdspraktiska sfären sker en översättning som länkar denna till de samhälleliga förändringar som berör föreställningar om det politiska subjektet (Ibid., s. 68).

Det betydelsefulla med den nya behandlingstanken är att den producerar en normaliseringsprocess som liknar den självdisciplinering som vi andra skall utföra. Detta kan bara göras samtidigt som kraven på "de normala" ökas kontinuerligt, eftersom vi är de egentliga adressaterna. Här är igen en ansvarsgörandeprocess, vi skall själva lösa våra problem via allt från privatpensionssparande till grannsamverkan mot brott. Kollektiva lösningar från välfärdsstaten tycks vara allt utom önskvärt.

\section{Differentiering, kategorisering och normalisering}

Precis som det alltid varit i fängelsets historia handlar den nya behandlingstanken om att producera normaliserande sanktioner. En kategorisering som tycks vara på väg tillbaka är den obotlige som varit frånvarande sedan de tidsobestämda påföljderna togs bort i Sverige i början på 1980-talet och Kriminalvårdsverket menar på att det igen i deras verksamhet finns personer som inte går att normalisera. Man säger också att "riktiga" fängelser är till för just dessa obotliga.

En central kritik som framfördes av de nordiska nyklassicisterna mot behandlingstanken på 1970-talet var att den hade lett fram till så många olika sanktionsformer, rättssystemet var så differentierat, att principen om likhet inför lagen, proportionalitetsprincipen, samt förutsägbarhetsprincipen var hotade (Andersson 2002). ${ }^{29}$ Vad vi kan se i dagens Sverige är att differentieringen återigen ökar med nya verkställighetsformer som elektronisk övervakning med fotboja och samhällstjänst. ${ }^{30} \mathrm{I}$ och med straffvärdeprincipens införande i Sverige sker dock inte differentierandet inom påföljdsvalsprocessen, utan på verkställighetsnivå där personutredningar får avgöra hur påföljden blir utformad. Här blir behovet att kategorisera ännu större, speciellt som behandlingsförespråkare menar att med mer specifika målgrupper för vilken olika vårdformer kan anpassas mer, ökar möjligheten till positiva resultat (se Lab 2004).

Förmågan att kategorisera och differentiera "brottslingar" är kanske kriminalvetenskapernas viktigaste uppgift och största insats för att producera en "fungerande" kriminalpolitik. ${ }^{31}$ På ett sätt skulle man kunna reducera de kriminalpolitiska debatter som förts under fängelsets historia till frågor om hur man mest vetenskapligt kategoriserar och differentierar brottslingar. Ser man historiskt till hur resultatlösa kriminalvetenskaperna varit i sin förmåga att träffa rätt borde blotta misstanken om en historielös behandlingsforskning väcka debatt. Ian Hacking (2000) skriver om något han benämner återkopplingseffekten i samhällsvetenskapen. Denna effekt innebär att "lyckade" kategoriseringar producerar mer forskning 
som ger fler experter, som skapar fler fall, som kräver mer åtgärder som då fordrar ytterligare forskning och så vidare. Kategoriseringarnas makt kan också exemplifieras med det Nicole Hahn Rafter (1997) skriver om i Creating born criminals. Ett av Hahn Rafters exempel är en person som fick tillbringa hela sitt liv på institution eftersom han diagnostiserats som born criminal. Utifrån dagens kategoriseringar hade samma person troligen definieras som lätt förståndshandikappad. Ett modernare exempel är rutinaktivitetsteoretikerna Stahura och Sloan som kategoriserar motiverade gärningsmän "som andelen av befolkningen i grannskapet som är färgade, fattiga, ungdomar eller arbetslösa" (Dolmén 2002:30). De kategoriseringar som kommer ur KBT handlar om felaktiga sätt att tänka. Dagens kategorisering av personer dömda upprepade gånger för brott är karriärkriminella. Detta är en kategorisering som tycks implicera att brottslighet är ett karriär val. Därigenom uppstår också möjligheten påverka detta val och behandlingen kan egentligen förstås som karriärvalsvägledning - tänk om gällande ditt val av karriär, är det verkligen detta du vill?

\section{Avslutande reflektioner}

Den moderna bestraffningsapparaten har allt sedan Benthams panopticon förmedlat en disciplineringsprocess som handlar om ett övervakande seende. Den gamla behandlingstankens disciplineringsprocess utgick från en hierarkisk övervakning påförd utifrån. Den nya utgår istället från en horisontal övervakning som skall komma inifrån för att manifestera sig utåt i ett personligt ansvar. Vad som eftersträvas är en självkännedom, tillgänglig via bekännelsen, som skall omsättas i ett handskande med sig själv och sina problem. Kognitiv beteendeterapi handlar om att förändra hur vi tänker, våra attityder, mål och önskningar. Vad som eftersträvas är att ge verktyg till subjektet så att denne kan bli en ansvarstagande person som kan komma att delta i den samhällsvision som formuleras så här i demokratiutredningen (SOU 2000:1, s. 20):

\footnotetext{
Medborgarna måste ges autonomi för att var för sig och i olika slag av gemensam självförvaltning i största möjliga utsträckning själva ordna sina liv. Den offentliga maktutövningen får inte klä av medborgarna denna vilja att ha kontroll över och ta ansvar för sina liv. Oavsiktligt kan detta dessvärre bli följden om stat och kommun övertar, inlemmar eller alltför okänsligt försöker styra verksamheter som medborgarna själva initierar eller organiserar. Man kan aldrig befria en människa från hennes självansvar. Varje människa måste känna ansvar för fler än sig själv. I princip måste därför varje tecken på att medborgare själva vill ta ansvar hälsas positivt.
}

Varför är då den nya behandlingsideologin så intressant? Därför att den samtidigt som den producerar kunskap om de subjekt som skall styras, även framställer praktiker för att omvandla dessa subjekt i enlighet med de mentaliteter och attityder som genomsyrar styrandet. Den nya behandlingstankens "uppgift" inom kriminalvården blir att realisera de föreställningar och mentaliteter som utgör den avancerade liberalismens styrningsrationalitet. 


\section{Referenslista:}

Andersson, R (2002), Kriminalpolitikens väsen, Avhandlingsserie nr. 10, Kriminologiska institutionen, Stockholms universitet.

Beck, U (2000), Risksamhället, Göteborg: Daidalos.

Brå-rapport 1999:4, Intensivövervakning med elektronisk kontroll. En utvärdering av 1997 och 1998 års riksomfattande försöksverksamhet, Stockholm: Brottsförebyggande rådet.

Bondeson, U (1974), Fången i fångsamhället, Stockholm: Nordstedts.

Castel, R (1991), "From dangerousness to risk" i Burcell, G, Gordon, C \& Miller, $\mathrm{P}$ (red.), The Foucault effect: Studies in governmentality, Chicago: University of Chicago Press.

Clarke, R.V (1980), "Situational crime prevention: Theory and practice", British Journal of Criminology, vol. 20, s. 136-147.

Dean, M (1999), Governmentality: Power and rule in modern society, London: Sage. Dir. 2002:90, En ny kriminalvårdslag.

Dolmén, L (2002), Brottslighetens geografi: En analys av brottsligheten $i$ Stockholms län, avhandlingsserie nr. 6, Kriminologiska institutionen, Stockholms universitet.

Feeley, M \& Simon, J (1992), "The new penology: Notes on the emerging strategy of corrections and its implications", Criminology, vol. 30, s. 449-474.

Feeley, M \& Simon, J (1994), "Actuarial justice: The Emerging new criminal law", i Nelken, D (red.), The Future of criminology, London: Sage.

Foucault, M (1987), Övervakning och straff, Lund: Arkiv.

Foucault, M (1991a), "Governmentality”, i Burcell, G, Gordon, C \& Miller, P (red.), The Foucault effect: Studies in governmentality, Chicago: University of Chicago press.

Foucault, M (1991b), "Politics and the study of discourse", i Burcell, G, Gordon, C \& Miller, P (red.), The Foucault effect: Studies in governmentality, Chicago: University of Chicago press.

Foucault, M (1991c), “Questions of method”, i Burcell, G, Gordon, C \& Miller, P (red.), The Foucault effect: Studies in governmentality, Chicago: University of Chicago press.

Foucault, M (2000), "About the concept of the 'the dangerous individual' in nineteenth-century legal psychiatry", i Faubion, J (red.), Power: Essential works of Foucault 1954-1984, vol. 3, New York: New Press.

Garland, D (1985), Punishment and welfare: A History of penal strategies, Aldershot: Gower.

Garland, D (1996), "The limits of the sovereign state: Strategies of crime control in contemporary society", British Journal of Criminology, vol. 36, s. 445-471. 
Garland, D (2001), The Culture of control: Crime and social order in contemporary society, Oxford: Oxford University Press.

Gordon, C (1991), "Governmental rationality: An introduction", i Burcell, G, Gordon, C \& Miller, P (red.), The Foucault effect: Studies in governmentality, Chicago: University of Chicago press.

Hacking, I (1991), "How should we do the history of statistics?", i Burcell, G, Gordon, C \& Miller, P (red.), The Foucault Effect: Studies in governmentality, Chicago: University of Chicago press.

Hacking, I (2000), Social konstruktion av vad?, Stockholm: Thales

Hahn Rafter, N (1997), Creating born criminals: Biological theories of crime and eugenics, Urbana: University of Illinois press.

Hughes, G (1998), Understanding crime prevention: Social control, risk and late modernity, Buckingham: Open university press.

Hultqvist, K \& Peterson, K (red.) (1995), Foucault: Namnet på en modern vetenskaplig och filosofisk problematik, Stockholm: HLS förlag.

Häthén, C (1990), Straffrättsvetenskap och kriminalpolitik: De europeiska straffteorierna och deras betydelse för svensk strafflagstiftning 1906-1931, Tre studier, akademisk avhandling, Lund: Lund University Press.

Hörnqvist, M (2004), 'Risken med riskbedömningar", Paper presenterat på NSfK: s forkarseminarium i Rörvig 23 april 2004.

Jareborg, N \& Zila, J (2000), Straffrättens påföljdslära, Stockholm: Nordstedts Juridik.

Johannisson, K (1994), Den mörka kontinenten: Kvinnan, medicinen och fin-desiècle, Stockholm: Norstedt.

KVS 1999, Med sikte på framtiden: En debattskrift om framtidens kriminalvård, Norrköping: Kriminalvårdsstyrelsen.

KVS 2002, What works III: Referat från den redje What works konferensen $i$ svensk kriminalvård, Norrköping: Kriminalvårdsstyrelsen.

Kärfve, E (2000), Hjärnspöken: DAMP och hotet mot folkhälsan, Stehag: Symposion.

Lab, S (2004), Crime prevention: Approaches, practices and evaluations, 5:e upplagan, Cincinnati: Anderson publishing.

Latour, B (1986), "Visualization and cognition: Thinking with eyes and hands", i, Knowledge and Society: Studies in the Sociology of Culture Past and Present, nr 6, s. 1-40.

Lernestedt, C (1996-97), "Något om grunden för den mänskliga ansvarsförmågan inom straffrätten", Juridisk Tidskrift, årg. 8, s. 323-351.

Levin, C (1998), Uppfostringsanstalten: Om tvång i föräldrars ställe, Lund: Arkiv förlag. 
Liedman, S-E (1998), Mellan det triviala och det outsägliga: blad ur humanioras och samhällsvetenskapernas historia, Göteborg: Daidalos.

Lipton, D, Martinson, R \& Wilks, J (1975), The Effectiveness of correctional treatment: A Survey of treatment evaluation studies, New York: Praeger.

McGuire, J (red) (2002), Offender rehabilitation and treatment: Effective programmes and policies to reduce re-offending, Chichester: Wiley.

Nettleton, S (1997), "Governing the risky self: How to become, healthy, wealthy and wise", i Petersen, A \& Bunton, R (red.), Foucault health and medicine, London: Routledge.

Nilsson, A (2002), Fånge i marginalen: Uppväxtvillkor, levnadsförhållanden och återfall i brott bland fångar, Avhandlingsserie nr. 8, Kriminologiska institutionen, Stockholms universitet.

Petersson, K (2002), Fängelset och den liberala fantasin: En studie om rekonstruktionen av det moraliska subjektet inom svensk kriminalvård, Filosofiska fakulteten, Linköpings universitet, Campus Norrköping.

Prop. 2000/01:76, Från anstalt till frihet.

Rose, N (1995a), "Politisk styrning, auktoritet och expertis i den avancerade liberalismen", i Hultqvist, K \& Peterson, K (red.), Foucault: Namnet på en modern vetenskaplig och filosofisk problematik, Stockholm: HLS förlag.

Rose, N (1995b), "Psykologens blick", i Hultqvist, K \& Peterson, K (red.), Foucault: Namnet på en modern vetenskaplig och filosofisk problematik, Stockholm: HLS förlag.

Rose, N (1998), Invetning our selves: Psychology, power and personhood, Cambridge: Cambridge University press

Rose, N (1999), Powers of freedom: Reframing political thought, Cambridge: Cambridge University Press.

Rose, N (2000), "The Biology of culpability: Pathological identity and crime control in a biological culture", Theoretical criminology, vol. 4, s. 5-34.

SOU 2000:1, En uthållig demokrati: Politik för folkstyre på 2000-talet, Betänkande av Demokratiutredningen.

SOU 2002:3, Psykisk störning, brott och ansvar, Betänkande av psykansvarskommittén.

Svensson, K (2001), I stället för fängelse? En studie av vårdande makt, straff och socialt arbete i frivård, Socialhögskolan, Lunds Universitet.

TEMANORD 2003:549, A lare bak murene: Utdannelse og kriminalomsorg $i$ ett livslangt loeringsperspektiv, Nordiska rådet.

Wallén, P-E (1979), Svensk straffrätts historia: Del 2, Stockholm: Gebers.

Ödman, P.J (1995), Kontrasternas spel: En svensk mentalitets- och pedagogikhistoria, Stockholm: Prisma. 
Noter:

1 Punkterna lever som sagt kvar än idag. Den första punkten utgör ju legitimeringen av påföljdssystemet genom tanken att vi bedriver en human kriminalvård, den andra punkten utgör förutsättningen för alla de kategoriseringar som genomskär kriminalvården. Den tredje punkten har framför allt gjort sig gällande $\mathrm{i}$ frågan om fakultativ villkorlig frigivning och den svenske justitieministern har nyligen framför att han vill införa möjligheten att styra strafftiden efter fångens uppförande. Punkt iv finns fortfarande kvar som ett viktigt led i återanpassning genom arbetsplikten. Den femte punkten är det utrymme vari behandling tar plats. Punkt vi är en punkt som kommer att beröras gällande dels frågan om expertis, dels att önskemål framförts i England om en ny kriminalvårdarutbildning. Slutligen har ju punkt vii nyligen utsatts för en reform genom införandet av intensivövervakning med elektroniskfotboja inför den villkorligt frigivna (prop. 2000/01:76).

2 Medicinska och biologiska modeller håller också på att göra sitt återtåg inom behandlingsforskningen (se exempelvis Rose 2000), denna artikel fokusera dock på de psykologiska modeller som ryms under KBT.

3 Det livslånga lärandet är en företeelse som kommit att bli en central föreställning inom allt som rör utbildning. Inom pedagogiken handlar i stort sett allt idag om att förbereda lärare och elever för det livslånga lärandet. Det livslånga lärandet handlar om att vi aldrig blir färdiga, examen uppnås aldrig - vi måste hela tiden höja vår kompetens, vidareutbildas, gå kurser och anpassas oss till den mobila arbetsmarknadens förväntningar. När då Nordiska rådet gör en genomgång av utbildningen i fängelset får också rapporten namnet Å lcere bak murene: Utdannelse og kriminalomsorg $i$ ett livslangt laeringsperspektiv (TEMANORD 2003:549).

$4 \quad$ Foucault (1987:353) säger att: "(j)ag påstår inte att de humanistiska vetenskaperna har uppstått ur fängelset. Men att de har kunnat formas och få den oerhörda kunskapsteoretiska verkan vi känner till, beror på att de burits av en ny, specifik maktmodalitet: en viss kroppens politik, ett visst sätt att göra anhopningen av människor fogliga och nyttiga. För detta krävdes att definierade relationer till vetandet infördes i maktförhållandena; det behövdes en teknik för att väva samman underkuvande och objektivering; det innebar nya individualiseringsprocesser. Fängelsernas nätverk utgör en stomme för en sådan kombination av makt och vetande, som historiskt sett gjort de humanistiska vetenskaperna möjliga".

5 I fråga om brott och brottslingar se exempelvis Hacking (1991), Foucault (1987; 2000) och Hughes (1998). I fråga om kunskap om det kvinnliga subjektet se exempelvis Johannisson (1994) och ifråga om pedagogik Ödman (1995).

6 Rose (1995b:177) menar att "individen trädde in i ett kunskapsfält, inte på grund av ett abstrakt språng in i den filosofiska fantasin, utan genom den byråkratiska dokumentationens jordnära operationer. Individualiseringsvetenskaperna utgick från befintliga tekniska rutiner för registrering, använde dem och transformerade dem till systematiska instrument för en inskription av identiteter: det var tekniker som förmådde översätta den mänskliga själens egenskaper, kapaciteter och energier till materiella former - bilder, kartor, diagram, mått”.

7 Sökandet och utrotandet av den sinnesslöa har sin grund i de föreställningar om Folkstammen och Rasen som var de rådande vid denna tid. Den sinnesslöas existens hotade helt enkelt att underminera Rasens fortlevnad. För en analys av rastänkandets betydelse för kriminalpolitiken se Garland (1985) och Hahn-Rafter (1997).

8 Enligt pedagogikprofessorn, Per-Johan Ödman, var en av skolans främsta uppgifter, och en anledning till dess uppkomst, att kontrollera och övervaka de barn som genom föräldrarnas förvärvsarbete inte längre stod under deras uppsikt (Ödman 1995, kap. 35 och 36).

9 Skolan som central i lokaliserandet av avvikelse eller åtgärd mot avvikelse kvarstår i dagsläget. Detta kommer exempelvis till uttryck i en önskan hos vissa forskare om att hitta tidigare och tidigare faktorer för prediktion. Ett annat exempel på skolans centrala betydelse framkommer när David Perry, chef för What works på Home Office, framhåller upptäckten att mellan 40 till 60 procent av hans klienter har en 7-årings läsförmåga. 
10 Tilltron till experternas kunskap kan exemplifieras med att de i flera länder framfördes förslag om att påföljdsbestämningen skulle skötas av läkare och psykiatrer. I Sverige är skyddslagsförslaget (SOU 1956:55) ett exempel på denna vetenskapsoptimism. I Storbritannien var Barbara Wotton en stark förespråkare för att helt avskaffa ansvarsfrågan och låta straffmätningen och påföljdsvalet skötas av experter (Lernestedt 1996-97).

11 För en utförlig diskussion om behandlingskritikens betydelse för svensk kriminalpolitik se Andersson (2002).

12 Skapandet av den nya medborgaren som är moralisk, ansvarstagande och förståndig (the prudent citizen) är avgörande i övergången till den styrningsrationalitet Mitchell Dean (1999) och Nikolas Rose (1999) benämner advanced liberalism. För hur den moraliske, ansvarstagande och förståndige medborgaren skapas i svensk kriminalpolitik se Andersson (2002, kap. 5).

13 Claes Levin (1998:80) skiljer mellan tre former av behandlingstanke. Den första handlar om en moralisk uppfostran av individer som uppstår under upplysningen - en pedagogisk behandlingstanke. Den hänger ihop med framväxten av individuppfattningen och föreställningen om individen som en tabula rasa som kan formas och utbildas. Ur denna förbättringstanke växer dels en medicinsk-rationell behandlingstanke som är starkt knuten till medicinens och psykiatrins framväxt, dels en socialpolitisk behandlingstanke som via institutioner som barnavårdsanstalter och missbruksanstaler skall uppfostra subjektet. I fokus för denna artikel är egentligen alla dessa tre former eftersom de epistemologier som undersöks genomskär alla tre formerna och skapar de subjekt som skall behandlas och förbättras.

14 Söker man på orden kognitiv beteendeterapi i Stockholms universitetsbiblioteks katalog får man 4440 träffar. De ämnen som berörs är allt från ätstörningar, spelberoende, kroniska depressioner, tinitus, schizofreni, kriser i äktenskapet och allmänt välbefinnande.

15 Så här säger man på Beteendeterapeutiska föreningens hemsida: "Det finns ingen enhetlig teori som förklarar alla psykiska problem eller ger riktlinjer för all slags behandling. Det kognitivtbeteendeterapeutiska arbetet utgår inte från några på förhand givna eller oomtvistade teorier utan bygger på forskning och praktisk erfarenhet. KBT är alltså i ständig utveckling” (www.kbt.nu).

16 I och för sig finns det likheter med den behavioristiska tankeformen, men inom KBT handlar det om mer än bara retningar och stimuli, det handlar om att förändra valet av handlingar, att förändra hur någon tänker om sina valmöjligheter. Det är just det att det finns valmöjligheter som ger förutsättandet av någon form av fri vilja.

17 KBT-programmen tycks handla om att lära ut giltiga tekniker för detta ommodellerande av en själv. 18 För en analys av risktänkandets betydelse i svensk kriminalpolitik se Andersson (2002)

19 För en analys av risktänkandet inom kriminalvården se Hörnqvist (2004). Risktänkandet är så centralt inom kriminalvården att det får en egen rubrik i den senaste psykansvarsutredningen (SOU 2002:3).

20 Inom den nya psykiatrin finns dock experten kvar som den som diagnostiserar och medicinerar. ADHD, CD, ASP och DAMP är bara några av de nya diagnoserna och kategoriseringar som snabbt vinner mark. I detta tänkande kvarstår expertstatusen och läkare-patient relationen, vad man givit upp är botandet, medicinen kan bara hjälpa patienten att handskas med sin "sjukdom". Dock är även dessa psykiatriska diagnoser beroende av kontextuella normativa föreställningar även om de ersätts med begrepp som har en förment objektiv status. För en studie kring DAMPdiagnosen se Kärfve (2000), om psykiatrisk och medicinsk forskning se Johannisson (1994).

${ }^{21}$ Detta kommer till uttryck i hur man definierar KBT som något som "(...) utgår inte från några på förhand givna eller oomtvistade teorier utan bygger på forskning och praktisk erfarenhet". Se fotnot 16.

22 Stefansson citerad i Petersson (2002:11).

23 Udden tycks egentligen mer vara riktad mot de utvärderingar som gjordes under 1970- och 80talen som exempelvis Lipton m.fl. (1975). Diskussionerna blir också av metodologisk art, det handlar om en förfining av mätinstrumenten, utvärderingsmetoderna och metaanalyser. 
24 Se exempelvis McGuire (2002).

25 Förvånande nog tycks inte återfall i brott var det viktigaste resultatmåttet, utan det handlar istället om att utvärdera attitydförändringar och socialkompetens hos de undersökta (Lab 2004). I presentationen av boken säger man bland annat att den "links theory, research and practice in a coherent way by providing a systematic, evidence-based approach for the effective reduction of criminal behaviour".

27 Sefbom (1999), citerad ur Petersson (2002).

28 Här kan vi se hur behandlingskritiskforskning, som Ulla Bondesons (1974) om prisonisering, kommit att påverka. Det man säger är ju att man vill undvika det som kallats prisonisering. I detta ligger också försök att handskas med en klassisk kritik mot behandling - att anpassningen kanske bara är ett spel som framförs av "den återanpassade" för att bli examinerad .

29 Regleringen av intensivövervakning strider mot dessa principer. För det första är det inte domstolen som beslutar om fotboja utan kriminalvårdsmyndigheterna (Jareborg \& Zila 2000). För det andra skall faktorer som utgår från subjektets personliga situation (att denne har bostad och ordnad sysselsättning, samt att subjektet själv får betala den kostnad övervakningen innebär) påverka huruvida någon får undergå intensivövervakning (Brå 1999:14). Sanktionsformen har också inneburit att fängelsepopulation blivit mer belastad och homogen (Nilsson 2002:35 ff.). Viljan att differentiera påföljdssystemet tycks kunna leda tillbaka till en situation som liknar den som rådde under den "gamla" behandlingstanken, numera kombinerat med ett risktänkande vilket framträder när kriminalvårdsstyrelsen menar att "(i) takt med att flera alternativa påföljder skapas framstår personutredningen ännu viktigare, inte minst för att ge underlag för val av lämplig påföljd” (KVS 1999:64).

31 När frivården växte fram i Sverige blev det direkt utmärkande för det hjälparbete som utvecklades att man började jämföra och kategorisera olika fångar. Tjänstemannens uppgift var t.ex. att urskilja vilka fångar som man skulle inrikta sin verksamhet på. Främst var det fångar som visat prov på anpassning och som rekommenderats av fängelsets ledning som var föremål för hjälpinsatser. Ett viktigt kriterium för att få hjälp var att de frigivna själva skulle vilja ha hjälp. De hjälpbehövande blev på så sätt allt mer väldefinierade, där vissa ansågs vara värda hjälpen och andra inte (Svensson 2001).

\author{
Adress: \\ Kriminologiska institutionen \\ Stockholms universitet \\ SE 10691 Stockholm \\ robert.andersson@crim.su.se
}

